\title{
Firm's Value Prediction Based on Profitability Ratios and Dividend Policy
}

\author{
T. Husain ${ }^{1 *}$, Sarwani ${ }^{2}$, Nardi Sunardi ${ }^{3} \&$ Lisdawati $^{4}$ \\ ${ }^{1,4}$ Doctoral Program Students, Faculty of Economics and Business, University of Persada Indonesia Y.A.I, Jakarta, Indonesia \\ 1, 2,3Management, Post Graduate Program, University of Pamulang, Tangerang City, Indonesia \\ ${ }^{4}$ Department of Management, University of Pamulang, Tangerang City, Indonesia \\ *Corresponding author: thusain050686@gmail.com \\ https://riiopenjournals.com/index.php/finance-economics-review/index
}

Doi: https://doi.org/10.38157/finance-economics-review.v2i2.102

Citation: Husain, T, Sarwani, Sunardi, N. \& Lisdawati (2020). Firm's Value Prediction Based on Profitability Ratios and Dividend Policy. Finance \& Economics Review, 2(2), 13-26. Doi: https://doi.org/10.38157/finance-economics-review.v2i2.102

\section{Research Article}

\begin{abstract}
Purpose: This study aims to empirically prove the research framework regarding the Firm's Value based on Profitability Ratios associated with Dividend Policy. The firm's Value is measured using a Price-toBook Value (PBV) Approach.

Methods: This study included a sample of 11 firms under the automotive and components sib sector listed in the Indonesia Stock Exchange. It included data for the period of 2014-2018. This study applied path analysis using the Sobel test of the direct and indirect effects using IBM SPSS 23.0.

Results: The study finds that Profitability Ratios has no significant effect on the Dividend Policy, while the Dividend Policy has no significant effect on Firm's Value too. However, the Dividend Policy does not mediate the effect of Profitability Ratios on the Firm's Value.

Implications: This study could be extended further by considering all listed firms of IDX which may provide us more insights into the measurement of the financial ratios in the context of Indonesia.
\end{abstract}

Keywords: Firm's Value; Profitability Ratios; Dividend Policy

\section{Introduction}

Dividend Policy is the firm's most important policy to determine the sustainability of a business. It can be understood as the approach of determining the amount of profits to be distributed to shareholders and retained for the corporate investment (Damayanti, Marwati, \& Widayanti, 2017). In evaluating the value of a company's stock equity, dividend policy becomes one of the most reliable parameters. Therefore, the reliability of the information in the financial statements regarding the company's performance is highly anticipated and expected by shareholders (Elinda \& Sukirman, 2015). The main motive of the investors or shareholders in investing in the part of the capital market is certainly inseparable from the company's dividend income. 
The automotive industry and the components sub-sector in Indonesia are attracting investors due to its attractive dividend payments. For example, (1) PT Astra International Tbk (ASII, trading symbol), declared Rp21.67 trillion net income in 2018 which is 15 percent higher than the previous year. It is one of the pull factors for shareholders and potential investors to invest (Aldin, 2019). (2) PT Selamat Sempurna Tbk (SMSM) booked a 59.79 percent dividend payout ratio (DPR) with a net profit of Rp556.9 billion (Brama, 2019). (3) PT Nipress Tbk which divested its shares to Johnson Controls Battery Investment (a subsidiary) worth Rp138.62 billion (OkeFinance, 2018). The three examples above imply the importance of dividend policy formulation in influencing the firm's value that is sourced from the measurement of profitability ratios. The firm's value becomes very important as an indicator of the benefits for shareholders and investors to make decisions. One manifestation of an investment decision is the share of profits to be paid to stakeholders as cash dividends, which is known as the dividend payout ratio (DPR). The DPR is a percentage of the source of funding to the investors in the form of dividend payments and the amount of profit that can be retained (Ismawati, 2017).

This research is motivated by several studies, which are (1) Liquidity, profitability and the dividends payout policy on the 24 UAE National Banks over the period 2005-2012 with the findings of the dividend payout ratio that has a significant and positive correlation with liquidity but the negative and insignificant correlation with profitability (Ahmed, 2015); (2)The determination of financial ratios to dividend policy on cash ratio, asset growth, debt-to-equity ratio, return on assets, and firm value. This study involves fifty-one firms listed in the LQ45 Stock Index companies in 2011-2013, with the findings of dividend policy caused by some factors such as return on assets and a debt-to-equity ratio (Elinda \& Sukirman, 2015) (3) The Impact of Dividend Policy on Firm's Value using dividend payout proxies on the Bucharest Stock Exchange for 2001-2011, with the findings that leverage and firm's size have a positive impact while profitability and liquidity do not have a statistically significant influence on firm's value (Anton, 2016). (4) The determination of dividend policy in telecommunications companies in Indonesia on ROE, and DER in six companies during the period of 2010-2015 with a proxy for dividend payout ratio. The findings illustrate the effect of ROE on dividend policy while CR and DER have no significant effect (Ismawati, 2017). (5) The effect of dividend policy on the stock's prices by involving 12 companies in the automotive sub-sectors and components of the 2008-2017 period. The findings of the research produce a dividend payout ratio's factor that has significance to the stock's price and also the significance of the dividend yields on the stock's price (Ermiati, Amanah, Harahap, \& Siregar, 2019). (6) The impact on the dividend payout ratio, before and after the recession using 13 companies, has issued IPO's in 2004 the NSE Listed Companies in India, with the findings that the dividend payout ratio for companies is not affected by the recession in 2007 (Kaur, Sunanda, \& Bhalla, 2019). (7)The effect of the company's size, profitability, and liquidity on the dividend policy and the company's value by involving 21 sample companies in 2013-2017. The findings prove that only the profitability of companies with ROA proxies has positive significance on the dividend policy and its implications for the firm's value (Akbar \& Fahmi, 2020). 
Business opportunities in the automotive and component industry's sectors in Indonesia have a wide market segment in the domestic and global markets. This industry has specifications in the manufacturing process through the process of printing (casting), forging (forging), pressing (stamping), and others. According to a report from the Ministry of Industry of the Republic of Indonesia, the export's achievements recorded that CBU and CKD exports recorded as many as 347 thousand units and components of more than 86.6 million pieces up to July 2019, which has exceeded 50 percent of the export's achievements in 2018. The industry is increasingly supported by 1,500 companies and 240 of them are members of the Association of Car and Motorcycle Equipment Industries (GIAMM) and 122 companies are members of the Automotive Components of Small and Medium Industry Association (PIKKO) while the automotive industry has contributed the Gross Domestic Product by 10.16 percent in 2017 with a target of 1.29 million vehicles by 2020. Focusing on accelerating the market's penetration in the context of Making Indonesia 4.0 (4IR) in this sector through the increasing volume of the local production, the efficiency of raw materials' production and the important components by adopting technology and infrastructure development, collaborating with the world OEM companies to increase exports, focusing on multi-purpose vehicles (MPV), low-cost vehicles environmentally friendly, and sport utility vehicles (SUV) and also building an ecosystem for the industry of electric vehicles $(\mathrm{EV})$, starting with the ability to manufacture electric motorcycles, then developing the ability of electric cars based on the inevitable adoption of EV's in the future (Kementerian Perindustrian RI, 2019).

This study aims to empirically prove the modeling of the firm's value based on the profitability ratio which is associated with dividend policy in the part of manufacturing various industries in sub-sectors of automotive and components listed in the Indonesia Stock Exchange (BEI) in 20142018. The difference between this study and the previous research is that this study uses the measurement of return on assets (ROA) in the profitability ratio because this sector becomes the subject of the research that largely invested in the asset component, which is a determinant factor in the formulation of dividend policy and can predict the performance of the firm's value.

\section{Literature Review and Hypothesis Development}

Profitability Ratio is a ratio that is used as a measurement of a company in getting profit with a percentage at an acceptable level. Profitability ratios can be measured by two approaches, which are sales and investment approaches. The measurements that are widely used among researchers are Return on Assets (ROA) and Return on Equity (ROE). The profitability ratio with the ROA and ROE proxy illustrates the attractiveness of the investment. The condition of a company that has a good profitability ratio encourages investors to make decisions. Investors with long-term portfolios tend to be interested in profitability analysis, for example, shareholders will observe price-to-book value (PBV) which illustrates the market's prospect of creating the firm's value for the amount of the invested capital. This study measures the company's profitability ratio based on the measurement of Return on Assets (ROA) which represents the company's profits with the calculation formula:

$R O A=\frac{\text { NetIncome }}{\text { Total Assets }}$ (Gitman \& Zutter, 2015, p. 51; Brigham \& Houston, 2016) 
Dividends are the company's tool for shareholders' profits that are derived from an organization. According to The Statement of Financial Accounting Standards (SFAC) Number 23, dividends are the distribution of profits to shareholders according to their proportion of certain types of capital. The company's net income will have an impact on retained earnings. If the retained earnings are distributed to shareholders, the retained earnings will be reduced by the distributed value (IAI, 2013). Dividend payments will be an expectation for investors that the company will have a high value. On the other hand, the continuity of the cash dividend distribution for companies is expected to contribute to the national economy and be able to provide results to shareholders. Some theories that underlie dividend policy in this study: (1) Dividend policy is irrelevant that the dividend payout ratio that determines the company's stock price does not influence the profit-making decision that is formulated, whether it will be distributed or retained earnings, while the company's value is determined by the earnings power of the company's assets to the capital's cost; (2) this can make the same investment's opportunities for investors and management going forward (Sartono, 2014, p. 281) and (3) BirdIn-The Hand Theory. This theory states that a bird in the hand will be more valuable than a thousand birds that fly in the air (Gordon \& Lintner, 1956), meaning investors will mathematically feel the same whether they will receive current dividends or receive capital gains in the future. The higher the stock market's price is, of course, the distributed dividends will also increase or vice versa (Sartono, 2014, p. 280; Titman, Keown, \& Martin, 2013). This study measures the dividend policy based on the measurement of the Dividend Payout Ratio (DPR) which represents the level of profit earned by shareholders on investment decisions (Titman, Keown, \& Martin, 2013, p. 606). The DPR's calculation formula is:

$D P R=\frac{\text { DividendperShare }}{\text { Earnings per Share }} \times 100 \%$ (Kaur, Sunanda, \& Bhalla, 2019)

The firm's value is an important concept for investors as a tool or indicator that is used to assess the company as a whole. The company's value is determined using several ratio analysis approaches based on market value consisting of price-to-book value ratio (PBVR), priceearnings ratio (PER), market book ratio (MBR), dividend yield ratio, and dividend payout ratio (Brigham \& Houston, 2016, p. 150). This valuation of ratio serves as a piece of output information to find out how much market is shared or the public will be interested in buying shares at a higher price than its historical value. The price-to-book value will be the target of the shareholders to increase the shareholders' prosperity (Mudjijah, Khalid, \& Astuti, 2019). This study measures the value of the company based on the measurement of Price-to-Book Value (PBV) that reflects the market value or book value of the firm's equity using the following calculation formula:

$P B V=\frac{\text { MarketPriceperShare }}{\text { Book Value per Share }}($ Ross, Westerfield, Jaffe, \& Jordan, 2016)

\subsection{Profitability Ratio's and The Dividend Policy}

Profitability is a measurement in detecting profit as a criterion for evaluating the results of the company's activities in a certain period. The amount of profit is a symbol or sign for the investors and corporate shareholders to split the dividends into large amounts. The level of profitability ratios with ROA proxy requires companies that have high profitability and large- 
scale pay a growing portion of income in the form of cash dividends. Previous studies described that no relationship between profitability and the dividend policy with ROA proxies (Ahmed, 2015). However, several studies documented a positive effect for Return on Assets towards the dividend policy (Elinda \& Sukirman, 2015; Ingrit, Siregar, \& Syarifuddin, 2017; Akbar \& Fahmi, 2020) then ROE proxies for financial ratio's (Ismawati, 2017). Based on the opposite findings in the literature, this study intends to address this issue further in the context of Indonesia which is stated by profitability ratios has a significant effect on the dividend policy $(\mathrm{H} 1)$.

\subsection{The Dividend Policy and Firm's Value}

The dividend policy shows the level of success of the company's failure in increasing the welfare of shareholders' in the form of net income that is ready to be distributed. Dividend policy is also a determination of the company's success in the context of financial performance. Previous studies described the effects of dividend payout ratio (DPR) on the firm's value (Anton, 2016). Then, a positive effect for the dividend payout ratio towards the stock's price which illustrates the firm's value on the investors' side (Ermiati, Amanah, Harahap, \& Siregar, 2019). Based on those few similar findings in the literature, this study intends to address this issue further in the context of Indonesia, which is stated by the dividend policy, which has a significant effect in the context of the firm's value $(\mathrm{H} 2)$.

\subsection{Profitability Ratio's, Dividend Policy and Firm's Value}

The previous related studies separately examined the indirect effects of profitability ratios to the dividend policy, and to test its impact in predicting the firm's value. The previous studies described that no relationship between the profitability and the firm's value with ROA proxies (Anton, 2016). However, the profitability of the companies with ROA proxies has a positive significance on dividend policy and its implications to the firm's value (Akbar \& Fahmi, 2020). This study also intends to address this issue further in the context of Indonesia by using the dividend payout ratio proxies as an intervening variable. This hypothesis is stated that the dividend policy mediates the effect of the profitability ratios on the firm's value (H3). Therefore, the design of the research's model in this study described:

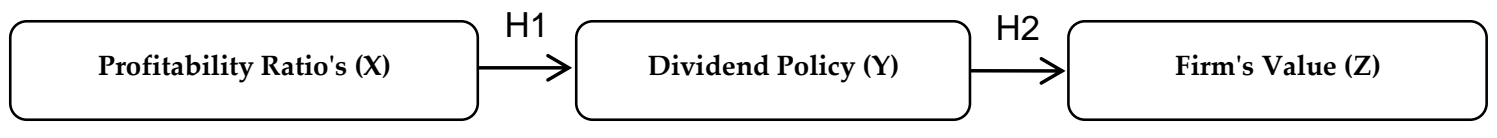

$\mathrm{H} 3=\mathrm{H} 1 \rightarrow \mathrm{H} 2$

\section{Fig.1. Research Model}

\section{Methodology}

It is a quantitative study based on published data collected from the annual reports of the sample firms. It tests hypotheses regarding the relationship between profitability ratios, dividend policy, and Firm's value. The purpose of this study is to examine and identify the $X$ variable, which are the profitability ratio, the $Y$ variable, the dividend policy and, the $Z$ variable, which is the Firm's Value. The population for this research comprises the firms under the automotive and components subsector listed in the Indonesia Stock Exchange during 2014-2018. 
The method of determining the samples is the purposive sampling technique that is used with confidence that the information needed for research will be obtained from one target group based on the criterion which is established by the researchers (Ali \& Limakrisna, 2013). The criteria for inclusion in the study include: (1) the part of manufacturing in sub-sectors of automotive and components in 2018; (2) The company did not conduct mergers and acquisitions during the 2014-2018 period; (3) The company did not experience delisting during the observation period; (4) The company issues a complete annual and financial report during the observation period; and (5) Companies that have currencies other than Rupiah in the reporting currency will be transformed into the exchange rate of Bank Indonesia (BI). The study includes 11 firms as its sample.

Table 1: Research Sample

\begin{tabular}{|lll|}
\hline Ticker Code & Firm's of Name & IPO Date \\
\hline ASII & PT Astra International Tbk & 04-Apr-1990 \\
\hline AUTO & PT Astra Otoparts Tbk & 15-Jun-1998 \\
\hline BRAM & PT Indo KordsaTbk & 05-Sept-1990 \\
\hline GDYR & PT Goodyear IndonesiaTbk & 01-Des-1980 \\
\hline GJTL & PT Gajah TunggalTbk & 08-Mei-1990 \\
\hline IMAS & PT Indomobil Sukses InternasionalTbk & 15-Sept-1993 \\
\hline INDS & PT IndospringsTbk & 10-Agus-1990 \\
\hline LPIN & PT Multi Prima SejahteraTbk & 05-Feb-1990 \\
\hline MASA & PT Multistrada Arah SaranaTbk & 09-Jun-1995 \\
\hline PRAS & PT Prima Alloy Steel UniversalTbk & 12-Jul-1990 \\
\hline SMSM & PT Selamat SempurnaTbk & 09-Sept-1996 \\
\hline
\end{tabular}

Source: (Saham OK, 2020)

Table 2: Variables of Measurement

\begin{tabular}{|llcl|}
\hline Variable & Proxies & Measurement & Scale \\
\hline $\begin{array}{l}\text { Profitability } \\
\text { Ratio's (X) }\end{array}$ & Return On Assets & $\frac{\text { NetIncome }}{\text { Total Assets }}$ & Ratio \\
\hline $\begin{array}{l}\text { Dividend } \\
\text { Policy (Y) }\end{array}$ & Dividend Payout Ratio & $\frac{\text { DividendperShare }}{\text { Earnings per Share }} \times 100 \%$ & Ratio \\
\hline Firm's Value (Z) & Price-to-Book Value & $\frac{\text { MarketPriceperShare }}{\text { Book Value per Share }}$ & Ratio \\
\hline
\end{tabular}

The method of data analysis is path analysis. Path analysis is an extension of the regression analysis with causal search which not only serves to find out the value of the magnitude of the influence but also the direct and indirect influence (Santosa A. D., 2019, p. 93). The path analysis model in this study is a model that is limited to the scope of only one path. The system of equations formulated in this research are:

$$
\begin{gathered}
\mathrm{Y}=\alpha+\beta 1 \mathrm{X}+\mathrm{e} 1 \ldots(1) \\
\mathrm{Z}=\alpha+\beta 2 \mathrm{Y}+\mathrm{e} 2 \ldots(2) \\
\text { Explanation: } \\
\mathrm{X} \quad: \text { Profitability Ratio's } \\
\mathrm{Y} \quad \text { : Dividend Policy } \\
\mathrm{Z} \quad \text { : Firm's Value }
\end{gathered}
$$


$\begin{array}{ll}\alpha & : \text { Constant } \\ \beta_{1} \ldots \beta_{2} & : \text { Regression of Coefficients } \\ \varepsilon & : \text { Error }\end{array}$

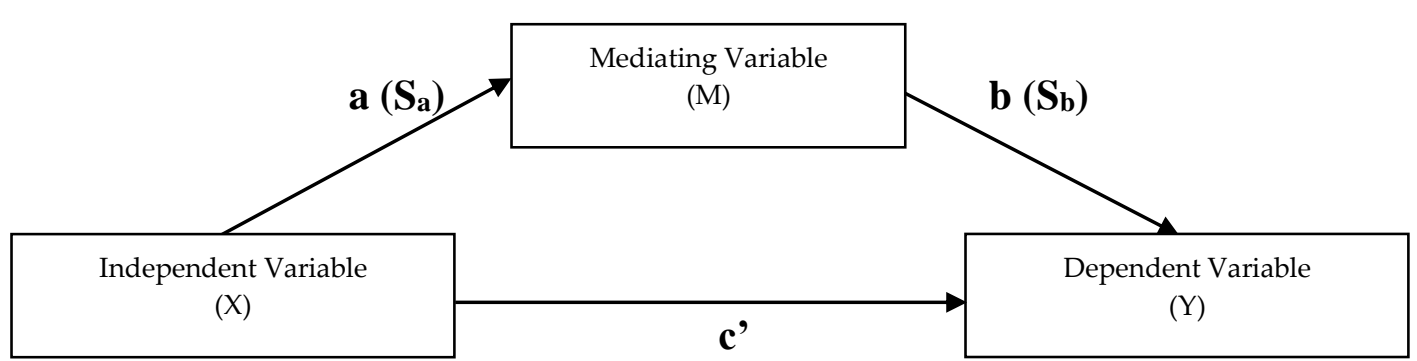

Fig.2. Relationship between Independent and Dependent Variables with the Effect of Mediator (Intervening) Variables

Source: (Ghozali, 2017, p. 247)

The Path analysis will be analyzed with the Sobel Test Technique to see the indirect effects or test the impact of the firm's value model in this study.

\section{Results and Discussion}

\subsection{Descriptive Statistics}

The Descriptive statistics are used to describe the data of the research's objects consisting of profitability ratios $(\mathrm{X})$, the dividend payout ratio $(\mathrm{Y})$ and the firm's value $(\mathrm{Z})$ with the part of manufacturing's sub-sectors of the automotive and components of 11 companies listed on the Indonesia Stock Exchange in periods 2014-2018.

Table 3: Descriptive Statistics

\begin{tabular}{|lllll|}
\hline Variable & Minimum & Maximum & Mean & Std. Deviation \\
\hline $\mathbf{X}$ & -0.1340 & 0.7160 & 0.049000 & 0.1171653 \\
\hline $\mathbf{Y}$ & -0.6046 & 3.5464 & 0.222778 & 0.5177191 \\
\hline $\mathbf{Z}$ & 0.1400 & 5.7700 & 1.2529091 & 1.2517657 \\
\hline
\end{tabular}

Source: Output from SPSS 23.00

The Profitability Ratios (X) with the Return on Assets (ROA) proxy has a mean score of 0.049000 with a standard deviation of 0.1171653 . That is, the eleven companies that were objects in this study had a relatively low average return on assets.

The Dividend Policy (Y) with a dividend payout ratio (DPR) proxy has a mean score of 0.222778 with a standard deviation of 0.5177191 . That is, the eleven companies that were objects in this study have an average value of the dividend payout ratio which is also relatively low.

The Firm's Value (Y) with a price-to-book value (PBV) proxy shows a mean score of 1.2529091 with a standard deviation of 1.25176568. That is, the eleven companies that were objects in this study have a pretty good price-to-book value (more than a score of 1 ). 


\subsection{Assessment of Classical Assumption Tests}

Table 4: Normality Tests (One-Sample Kolmogorov-Smirnov Test)

\begin{tabular}{|ll|}
\hline & Un-standardized Residual \\
\hline $\mathrm{N}$ & 55 \\
\hline Kolmogorov-Smirnov Z & 1.142 \\
\hline Asymp Sig. (2-tailed) & 0.147 \\
\hline
\end{tabular}

Source: Output from SPSS 23.00

The results of the normality testing with the Kolmogorov-Smirnov $(K / S)$ technique resulted in a score of 1.142 and a significant probability of 0.147 (greater than 0.05 ) or in other words, H0 is acceptable. The residual value in this test can be concluded that it has followed the normal data distribution function.

Table 5: Summary of Multicollinearity Tests

\begin{tabular}{|lllll|}
\hline Model & \multicolumn{2}{l}{ Regression 1} & \multicolumn{2}{l|}{ Regression 2} \\
\cline { 2 - 5 } Independent & Tolerance & VIF & Tolerance & VIF \\
Variables & Score & Score & Score & Score \\
\hline $\mathrm{X}$ & 1.000 & 1.000 & 0.986 & 1.014 \\
\hline $\mathrm{Y}$ & - & - & 0.986 & 1.014 \\
\hline
\end{tabular}

Source: Output from SPSS 23.00

The results of multicollinearity testing in tolerance score on each variable greater $(>)$ than 0.1 and a VIF score smaller $(<)$ than 10. The regression model is stated to be clear from the multicollinearity problems in each independent variable.

Table 6: Summary of HeteroskedastisityTests (Correlation of Spearman's Rho)

\begin{tabular}{|ll|}
\hline Variables & Significant Score \\
\hline $\mathrm{X}$ & 0.423 \\
\hline $\mathrm{Y}$ & 0.319 \\
\hline
\end{tabular}

Source: Output from SPSS 23.00

The results of heteroskedasticity with the Spearman's rho correlation technique produces a probability score of significance greater than $(>)$ of 0.05 to see heteroskedasticity. The regression model can be stated does not occur heteroskedasticity problems.

Table 7: Summary of Autocorrelation Tests

\begin{tabular}{|c|c|c|c|c|}
\hline \multirow{2}{*}{ Model } & \multicolumn{4}{|l|}{ Score } \\
\hline & $\mathrm{dU}$ & $\mathrm{dL}$ & 4-dU & $\mathrm{dW}$ \\
\hline 1 & 1.6014 & 1.5276 & \multirow{2}{*}{2.3986} & 1.983 \\
\hline 2 & 1.6014 & 1.5276 & & 0.495 \\
\hline
\end{tabular}

The results of autocorrelation test results produce a Durbin Watson $(\mathrm{dW})$ score each of the regression models 1 and score is 1.983 and 0.495 . The autocorrelation test requires the regression model to be in the range of score $\mathrm{du} \leq \mathrm{dW} \leq(4-\mathrm{du})$. The $\mathrm{dW}$ score in the regression model 1 is in the range of score $\mathrm{dU} \leq \mathrm{dW} \leq(4-\mathrm{dU})$ which means there is no positive or negative autocorrelation while the DW score in the regression model 2 is in the range of scores $0<\mathrm{dW}<$ $\mathrm{dL}$ which means there is no positive autocorrelation (reject $\mathrm{H} 0$ ) and can be stated the existence of autocorrelation between residual values. To overcome the autocorrelation problem in this 
research, the Cochrane Orcutt technique can be used as an alternative by making the following new equation:

$$
\mathrm{yt}=\alpha+\mathrm{Xt} \beta+\varepsilon \mathrm{t}
$$

Explanation:

yt : dependent variable that follows time $(\mathrm{t})$

B : Estimated beta coefficient

$\varepsilon \quad:$ Error

Table 8: Summary of Autocorrelation Tests (Cochrane Orcutt)

\begin{tabular}{|c|c|c|c|c|}
\hline \multirow{2}{*}{ Model } & \multicolumn{4}{|l|}{ Score } \\
\hline & $\mathrm{dU}$ & $\mathrm{dL}$ & $4-\mathrm{dU}$ & $\mathrm{dW}$ \\
\hline 2 & 1.6014 & 1.5276 & 2.3986 & 1.825 \\
\hline
\end{tabular}

After the autocorrelation testing through the Lag (1) form of 0.830 to determine the Rho autocorrelation coefficient (๑)of the transformation results, a Durbin Watson (dW) score of 1.825 was obtained in the regression model 2 , this means that the $\mathrm{dW}$ score was at a dU $<\mathrm{dW}<4-\mathrm{dW}$ score (accepts H0). The overall results of the autocorrelation test on the two regression models have resulted in the absence of autocorrelation either positive or negative.

\subsection{Assessment of Linearity}

The evaluation of the fulfillment of assumptions in the path analysis needs to be tested before testing the hypothesis so that the model's specifications are right through a linearity test. The approach used is the Curve Fit Technique which the interpretation refers to the parsimony of the concepts i.e. if all the models tested are significant or not significant, the linear function is significant, meaning the model can be said to be linear. The model's specifications that use as a basis for testing are using linear, quadratic, cubic, inverse, logarithmic, power, S, compound, growth, and exponential units.

Table 9: Summary of Linearity Tests (Curve Fit)

\begin{tabular}{|c|c|c|c|c|c|c|c|}
\hline $\begin{array}{l}\text { Regression } \\
\text { Model }\end{array}$ & $\begin{array}{l}\text { Specification } \\
\text { Model }\end{array}$ & $\mathbf{R}^{2}$ Score & $\begin{array}{l}\text { F } \\
\text { Statistics }\end{array}$ & df1 & df2 & $\begin{array}{l}\text { Significant } \\
\text { Score }\end{array}$ & Conclusion \\
\hline$X \rightarrow Y$ & Quadratic & 0.085 & 2.422 & 2 & 52 & 0.099 & No Significant \\
\hline $\mathbf{Y} \rightarrow \mathrm{Z}$ & Quadratic & 0.177 & 5.574 & 2 & 52 & 0.006 & Significant \\
\hline
\end{tabular}

Based on the results of the linearity test, it can be seen that all the relationships between variables $\mathrm{Y} \rightarrow \mathrm{Z}$ (function as an intervening) in this research show a linear relationship, so that the analysis model made is feasible to be applied.

\subsection{Hypothesis of Testing}

Hypothesis testing is intended to scientifically prove the modeling of a firm's value based on financial ratio's mediated by the dividend policy conducted by path analysis. The results of the linear regression equation for each model 1 and 2 are:

$$
\begin{aligned}
& Y=0.197+0,527 X \ldots(1) \\
& Z=1,157+0,430 Y \ldots \text { (2) }
\end{aligned}
$$




\section{Table 10: Summary of the Coefficients of Total Determination $\left(\mathbf{R m}^{2}\right)$}

\begin{tabular}{|llll|}
\hline \multirow{2}{*}{ Model } & \multicolumn{2}{l}{ Score } & \\
\cline { 2 - 4 } & $\mathbf{R}$ & $\mathbf{R}^{2}$ & $\begin{array}{l}\text { Std. Error of } \\
\text { the Estimate }\end{array}$ \\
\hline Regression 1 & 0,119 & 0.014 & 0.5188486 \\
Regression 2 & 0.178 & 0.032 & 1.2433907 \\
\hline
\end{tabular}

Source: Output from SPSS 23.00

The standard arithmetic results error of the estimate from Regression Model 1:

$P e 1=\sqrt{1-R 2}=\sqrt{1-0.06}=\sqrt{0.94}=0.9695$

The standard arithmetic results error of the estimate from Regression Model 2:

Pe2 $=\sqrt{1-R 2}=\sqrt{1-0.083}=\sqrt{0.917}=0.9576$

Based on the total determination of the data in the regression model above, it can be calculated using the formula:

$$
\begin{aligned}
& \mathrm{Rm} 2=1-\mathrm{P} 2 \mathrm{e} 1 \mathrm{P} 2 \mathrm{e} 2 \\
& \mathrm{Rm} 2=1-(0.993)^{2} \times(0.9839)^{2} \\
& \mathrm{Rm} 2=1-(0.9861 \times 0.9681) \\
& \operatorname{Rm} 2=1-0.9546 \\
& \operatorname{Rm} 2=0.0454
\end{aligned}
$$

The coefficient of total determination ( $\mathrm{Rm} 2)$ results in a score of 0.0454 , meaning that 4.54 percent of the variable of the firm's value variable can be identified by the profitability ratios variable with the return on assets (ROA) proxy and the dividend policy variable with the dividend payout ratio (DPR) proxy whereas the remaining 95.46 percent is identified by other factors which are not included in the research model.

\begin{tabular}{|llll|}
\multicolumn{4}{|c|}{ Table 11: Path Analysis Test Results (Direct Effect) } \\
\hline \multirow{2}{*}{ Path } & Score & & \\
\cline { 2 - 4 } & Relationship between & $\begin{array}{l}\text { Standardized } \\
\text { Beta }(\boldsymbol{\beta})\end{array}$ & Significant \\
& Variables & 0.527 & 0.385 \\
\hline p1 & $\mathrm{H} 1: \mathrm{X} \rightarrow \mathrm{Y}$ & 0.430 & 0.194 \\
p2 & $\mathrm{H} 2: \mathrm{Y} \rightarrow \mathrm{Z}$ & & \\
\hline
\end{tabular}

The results of the path analysis test reveal that both regression models produce a significance probability greater than $(>\mathrm{Z})$ so that they refuse $\mathrm{H} 1$ and H2. Furthermore, the results of the H3 test through path analysis gives an indirect effect through the Sobel test.

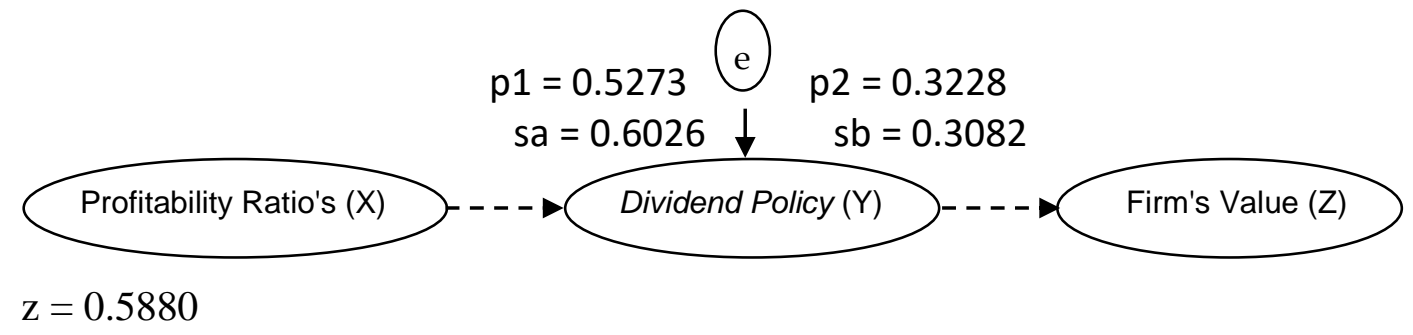

Fig.3. Effect between Variables in the Research Model 
The results of the Sobel test on indirect effects produce an indirect effect on the profitability ratios to the firm's value through the dividend policy, the magnitude of the indirect effect is 0.1702 from the multiplication coefficient between $b$ (MX) or path $\mathrm{p} 1$ to $\mathrm{b}$ (YM.X). The mediation coefficient value 0.1702 is with a significant probability of 0.5880 (greater than 0.05 ). The standard error value is 0.3142 so the calculated $t$-statistics becomes:

$$
\mathrm{t}=\frac{0,1702}{0,3142}=0,9606
$$

The $t$-statistics of 0.9606 results a smaller score $(<)$ than $t$-table (1.96) so it rejects H3. The dividend policy variable does not mediate the influence of profitability ratios on the firm's value.

\subsection{Discussion}

The results of the study of the three alternatives' hypotheses that are mentioned above are not proven to have a significant effect. In other words, this study empirically proves that the effect of the profitability ratios on the dividend policy and their implications on the firm's value does not support previous studies reviewed with the following results:

H1) The $t$-statistics for the profitability ratios variable of 0.875 with a significant probability of 0.385 so that it rejects H1. This hypothesis does not statistically prove that the profitability ratios with the return on assets (ROA) proxy has a significant effect on the dividend policy. The findings of this study are contrary to the use of the return on assets proxy that has a positive effect on the dividend policy where companies' report earnings will tend to pay a greater portion as dividends, as seen from the value of the dividend payout ratio (DPR) (Elinda \& Sukirman, 2015; Ingrit, Siregar, \& Syarifuddin, 2017) while the findings are similar to the insignificant relationship between profitability and the dividends payout policy (Ahmed, 2015). The rate of return on capital with a proxy on return on equity (ROE) has a positive influence on the dividend policy, where capital is raised from shareholders should be maximally utilized to be able to generate high profit so that the payout ratio is increasing (Ismawati, 2017). Furthermore, the increase of the firm's value is caused by the positive influence of the profitability with the proxy for return on assets (Akbar \& Fahmi, 2020). The size of the return on assets that illustrates the profitability ratios in this study does not have an impact on the formulation of the dividend policy.

H2) The t-statistics for the dividend policy variable of 1.315 with a significant probability of 0.194 so that it rejects H2. This hypothesis does not statistically prove that the dividend policy with the dividend payout ratio (DPR) proxy has a significant effect on the firm's value. The findings of this study are similar to the use of the dividend payout ratio proxy has no significant influence towards the firm's value (Anton, 2016) while the findings of this study are contradictory which show a positive effect for the dividend payout ratio toward stock price (Ermiati, Amanah, Harahap, \& Siregar, 2019). The increase in the firm's value is positively marked by the investors' perceptions that are assessed based on the company's dividend policy when the company can take advantage of the opportunities and make efficiency in carrying out its operational activities to be a signal 
to the investors that the company has increased profits (Mudjijah, Khalid, \& Astuti, 2019). The low DPR ratio in this study does not necessarily indicate that a company will share a large number of its profits to investors in the context of price-to-book value (PBV), but rather a low level of the dividend payment to reinvest a large portion of its net income into a company's opportunity in order to increase the firm's value.

H3) The t-statistics for the dividend policy variable which mediates the effect of the profitability ratios on the firm's value obtained equal to 0.9606 with a significant probability of 0.5880 so that it rejects $\mathrm{H} 3$. This hypothesis does not statistically prove that the dividend policy functions as an intervening variable that is mediating the effect of the profitability ratios on the firm's value. The findings of this study are basically linear with the proof of the results on the size of the company that does not have a significant effect on the firm's value (Akbar \& Fahmi, 2020), but the moderate function of the financial performance in return on assets (ROA) can be more flexible in managing resources and improving the financial performance with a PBV proxy (Mudjijah, Khalid, \& Astuti, 2019). This condition will have an impact on sales and increase company profits so that the size of the dividend policy formulation to increase shareholders' welfare in this study cannot be used as a measurement of increasing the firm's value.

\section{Conclusions and Suggestions}

The conclusions from the results of the research and discussion are:

1) Profitability Ratio has no significant effect on the Dividend Policy

2) Dividend Policy has no significant effect on the Firm's Value

3) Dividend Policy doesn't mediate the effect of Profitability Ratios on the Firm's Value The company's evaluations of the formulation of the dividend policy should consider better measurement of the financial ratios, not only based on the profitability (return on assets - ROA) but also return on equity (ROE). Proxies can be involved in other financial ratios such as activity ratios, liquidity ratios, solvency ratios, and market prospect ratios so that the results can be more representative of the existing conditions in Indonesia.

The present research framework regarding the firm's value can use alternative measurements such as the price-earnings ratio (PER), market book's ratio (MBR), and Tobin's Q ratio. Besides that, return on equity (ROE) proxies can be added with ROA proxies so that it can improve the findings and results in future studies.

Conflicts of Interest: The authors declare no conflict of interest.

Author Contributions: T. Husain and Sarwani conceived the idea and collected data; T. Husain analyzed the data; T. Husain wrote the paper.

\section{REFERENCES}

Ahmed, I. E. (2015). Liquidity, Profitability, and the Dividends Payout Policy. World Review of Business Research, 5 (2), 73-85. 
Akbar, F., \& Fahmi, I. (2020). Effect of Company Size, Profitability, and Liquidity on Dividend Policy and Company Value on Manufacturing Companies Listed on the Indonesia Stock Exchange. Jurnal Ilmiah Mahasiswa Ekonomi Manajemen, 5 (1), 62-81.

Aldin, I. U. (2019, April 25). Rekor! Dalam Setahun Lebih 50 Perusahaan IPO pada 2018. (R. Iskana, Ed.) Retrieved Januari 31, 2020, from Kata Data: https://katadata.co.id/berita/2019/04/25/astra-international-bagikandividen-yang-totalnya-rp-866-triliun

Ali, H., \& Limakrisna, N. (2013). Metodologi Penelitian (Petunjuk Praktis untuk Pemecahan Masalah Bisnis, Penyusunan Skripsi, Tesis, dan Disertasi) (1 ed.). Yogyakarta: Deepublish.

Anton, S. G. (2016). The Impact of Dividend Policy on Firm Value. A Panel Data Analysis of Romanian Listed Firms. Journal of Public Administration, Finance, and Law (10), 107-112.

Brama, A. (2019, Mei 7). Selamat Sempurna (SMSM) akan bagi dividen sebesar Rp 18 per saham. (N. Laoli, Ed.) Retrieved Januari 31, 2020, from Kontan.co.id: https:/investasi.kontan.co.id/news/ selamat-sampurna-smsm-akanbagi-dividen-sebesar-rp-18-per-saham

Brigham, E. F., \& Houston, J. F. (2016). Fundamentals of Financial Management (14 ed.). (J. Sabation, Ed.) Boston: Cengage Learning.

Damayanti, R., Marwati, F. S., \& Widayanti, R. (2017). Dividend Policy Analysis Based on Lintner's Theory. AGREGAT: Jurnal Ekonomi dan Bisnis , 1 (2), 183-194.

Elinda, F., \& Sukirman. (2015). Determinants of Financial Ratios on Dividend Policy. Accounting Analysis Journal, 4 (4), 1-8.

Ermiati, C., Amanah, D., Harahap, D. A., \& Siregar, E. S. (2019). Effect of Dividend Policy on Share Prices of Automotive Sub Sector Companies and Components Registered on the Indonesia Stock Exchange for the period 2008-2017. NIAGAWAN, 8 (2), 131-139.

Ghozali, I. (2017). Aplikasi Analisis Multivariate Dengan Program: IBM SPSS 23 (VIII ed.). Semarang: Badan Penerbit UNDIP.

Gitman, L. J., \& Zutter, C. J. (2015). Principles of Managerial Finance (14 ed.). (D. Battista, Ed.) Boston: Prentice-Hall.

IAI. (2013). Pernyataan Standar Akuntansi Keuangan. Jakarta: Dewan Standar Akuntansi Keuangan - Ikatan Akuntan Indonesia.

Ingrit, Siregar, H., \& Syarifuddin, F. (2017). Factors Influencing Dividend Policy on Mining Companies Listed in Indonesia Stock Exchange 2011-2015. International Journal of Administrative Science E Organization, 24 (2), 9199.

Ismawati, L. (2017). Determinants of Dividend Policy in Telecommunication Companies in Indonesia. Jurnal Inspirasi Bisnis dan Manajemen , 1 (1), 11-18.

Kaur, D. M., Sunanda, \& Bhalla, D. L. (2019). Impact on the dividend payout ratio before and after the recession- A Study on NSE Listed Companies. Journal of The Gujarat Research Society, 21 (8s), 518-532.

Kementerian Perindustrian RI. (2019). Industri Komponen Topang Daya Saing Sektor Otomotif Nasional. Jakarta: Humas Kementrian Perindustrian.

Kementerian Perindustrian RI. (2019). Making Indonesia 4.0. Jakarta: Humas Kementrian Perindustrian.

Mudjijah, S., Khalid, Z., \& Astuti, D. A. (2019). The Influence of Financial Performance and Capital Structure on Firm Value that is Moderated by Company Size Variable. Jurnal Akuntansi dan Keuangan , 8 (1), 41-56.

OkeFinance. (2018, Oktober 3). Nipress Lepas Saham NEO Ke Johnson Controls Senilai Rp138,62 Miliar. Retrieved January 31, 2020, from https://economy.okezone.com/read/2018/10/03/278/ 1959119/nipress-lepas-sahamneo-ke-johnson-controls-senilai-rp138-62-miliar

Ross, S., Westerfield, R., Jaffe, J., \& Jordan, B. (2016). Corporate Finance (11 ed.). (J. Haine, Ed.) New York: Mc GrawHill Education.

Saham OK. (2020, February 10). Sub sektor otomotif \& komponen BEI (42) - Industri Manufaktur. Retrieved May 22, 2020, from https://www.sahamok.com/emiten/sektor-aneka-industri/sub-sektor-otomotif-komponen/

Santosa, A. D. (2019). Analisis Multivariat (Cetakan Ketiga). Yogyakarta: Penerbit Kepel PRESS.

Santosa, A. D. (2020). Teori dan Aplikasi Penelitian Kuantitatif dengan Menggunakan Metode SEM (Cetakan Ketiga) (Revisi ed.). Yogyakarta: Kepel PRESS.

Sartono, R. A. (2014). Manajemen Keuangan Teori dan Aplikasi (Edisi 4). Yogyakarta: BPFE Yogyakarta. 
Titman, S., Keown, A. J., \& Martin, J. D. (2013). Financial Management: Principles and Applications (12 ed.). Boston, USA: Prentice-Hall. Attribution (CC BY) license (http://creativecommons.org/licenses/by/4.0/). 